\title{
Pengetahuan Perawat Tentang Pentingnya Dokumentasi Keperawatan di Ruang Rawat Inap
}

\author{
Dea Kristin Sania Manik \\ Deakristin01@gmail.com
}

\section{LATAR BELAKANG}

Dokumentasi keperawatan sangatlah penting, akan tetapi pada kenyataannya masih banyak perawat yang kurang mengetahui dokumentasi keperawatan yang baik dan benar. okumentasi keperawatan mempunyai makna penting dalam aspek hukum, kualitas pelayanan, komunikasi, pendidikan, penelitian, dan akreditasi. Berkaitan dengan perlindungan hukum, dokumentasi asuhan keperawatan dapat memberi bukti yang berharga tentang kondisi pasien dan pengobatannya dan dapat bersifat kritis dalam menentukan standar perawatan apakah telah dipenuhi atau tidak (Nursalam, 2008).

Dokumentasi Asuhan Keperawatan merupakan informasi tertulis tentang status dan perkembangan kondisi klien serta semua kegiatan asuhan keperawatan yang dilakukan oleh perawat (Fisbach,1991). Nursalam (2008) menyebutkan instrument studi dokumentasi penerapan standar asuhan keperawatan di RS menggunakan instrument A dari DEPKES (1995) yang meliputi standar I (Pengkajian Keperawatan), standar II (Diagnosa Keperawatan) ,standar III (Perencanaan Keperawatan), standar IV (Intervensi Keperawatan), standar V Evaluasi Keperawatan), standar VI (Catatan Asuhan Keperawatan).

Komponen dokumentasi asuhan keperawatan meliputi komponen isi dokumentasi dan komponen dalam konsep penyusunan dokumentasi. Komponen isi dokumentasi meliputi: pengkajian, diagnosis keperawatan, rencana keperawatan, pelaksanaan tindakan keperawatan, evaluasi, pengesahan (tanda tangan/paraf dan nama terang perawat), dan catatan keperawatan diisi secara lengkap dan jelas, resume keperawatan (Catatan pasien pulang atau meninggal dunia) 
Standar asuhan keperawatan diberlakukan di seluruh rumah sakit melalui Surat keputusan direktur jenderal pelayanan medik nomor: YM.00.03.2.6.7637 tahun 1993 tentang berlakunya standar asuhan keperawatan di rumah sakit. Standart Operating Procedure (SOP) merupakan akitivitas dari NIC (Nursing Intervention Classification). NIC (Nursing Intervention Classification) adalah sistem klasifikasi perawatan yang menggambarkan kegiatan yang dilakukan oleh perawat sebagian bagian dari proses keperawatan yang berasosiasi dengan pembuatan rencana asuhan keperawatan. Secara konseptual prosedur diartikan sebagai langkah langkah sejumlah instruksi logis untuk menuju pada suatu proses yang dikehendaki. Proses yang dikehendaki tersebut berupa pengguna-pengguna sistem proses kerja dalam bentuk aktivitas, aliran data, dan aliran kerja.

\section{Kata Kunci : Dokumentasi, Perawat, Pengetahuan}

\section{METODE}

Penulisan ini dilakukan dengan metode kajian bebas terhadap pokok bahasan yang di kumpulkan dari beberapa sumber yang berkaitan dengan pokok bahasan, seperti jurnal online maupun jurnal print, dan buku online.

Setelah membaca beberapa jurnal dan menyeleksinya penulis menentukan 10 jurnal yang dipilih.

Alasan jurnal yang di pilih diantaranya :

a. Sumbernya jelas

b. Sesuai dengan topik yang diinginkan

c. Batas tahun diterbitkannya artikel tidak lebih dari 10 tahun

\section{HASIL PENELITIAN}

Asuhan keperawatan professional merupakan kegiatan melaksanakan asuhan keperawatan kepada klien berdasarkan ilmu dan kiat keperawatan, bersifat "humane", dengan pendekatan holistik, mencakup biopsiko- sosial/kultural dan spiritual, serta orientasi kebutuhan 
objektif klien, dalam bentuk praktik keperawatan ilmiah (Kusnanto, 2004). Perawat dan praktik keperawatan tergambar setiap hari bagi yang membaca catatan pasien. Data keperawatan yang terdapat dalam catatan merefleksikan standar asuhan keperawatan.dan anggota tim kesehatan lain membuat keputusan perawatan berdasarkan catatan keperawatan. Pencatatan telah dipandang sebagai riwayat sekunder untuk perawatan pasien (Marrelli, 2008).

Hasil penelitian menunjukkan perawat yang pengetahuannya terkait dokumentasi keperawatan rendah, ada sejumlah 58,3\% yang dokumentasi keperawatannya lengkap. Sedangkan perawat yang memiliki pengetahuan dokumentasi keperawatan tinggi, ada sebanyak 56,2\% yang dokumentasi keperawatannya lengkap. Hal ini bertentangan dengan penelitian Fizran dan Mamdy (2002) yang mendapatkan bahwa tingkat pengetahuan berhubungan secara bermakna dengan kinerja perawat dalam pendokumentasian keperawatan. Begitu pula dengan penelitian Kusumawaty dan Yani (2001) yang mendapatkan bahwa adanya hubungan bermakna dan berpola positif antara pemahaman terhadap pendokumen-tasian proses keperawatan dengan kompetensi mendokumentasikan proses keperawatan. Asumsi peneliti menyatakan bahwa pengetahuan tinggi tidak selalu menunjukkan pelaksanaan doku-mentasi keperawatan yang lengkap.

Menurut analisis peneliti ada beberapa faktor yang dapat menunjang terjadinya ketidaklengkapan dokumentasi pengkajian keperawatan adalah : 1) karakteristik perawat pelaksana didominasi oleh perawat yang berumur muda yang belum lama memiliki pengalaman bekerja, 2) pengkajian, diagnosis, dan perencanaan keperawatan semestinya dilakukan oleh ketua Tim yang mempunyai kompetensi baik dalam hal proses asuhan keperawatan akan tetapi di ruang rawat inap non intensif Rumah Sakit X penkajian sampai evaluasi dilakukan oleh semua perawat walupun perawat itu masih miskin pengalaman, 3) Supervisi terhadap dokumentasi pengkajian oleh atasan langsung tidak maksimal dilakukan yang ditunjukan dengan tidak adanya bukti dokumen dimaksud telah disupervisi (seperti paraf, komentar, ataupun jenis koreksi lainnya), 4) Pelatihan tentang sistem dokumentasi ini tidak pernah dilakukan dalam lima tahun terakhir ini, 5) Baik Uraian tugas perawat pelaksana maupun Ketua Tim tidak menyebutkan secara rinci perintah atau petunjuk tentang bagaimana membuat dokumentasi asuhan keperawatan yang baik dan benar, 6).Audit keperawatan yang berkaitan dengan dokumentasi proses asuhan keperawatan tidak pernah dilakukan dalam dua tahun terakhir ini.

\section{PEMBAHASAN}


Menurut Brian Gugerty, et all dalam Challenges and Opportunities in Documentation of the Nursing Care of Patients Report of the Maryland Nursing Documentation Work Group (2007), perawat setiap harinya dalam melakukan rutinitas menghabiskan 15-25 \% waktunya digunakan untuk mendokumentasikan asuhan keperawatan. Tetapi perawat menganggap bahwa dokumentasi tidak penting atau berlebih-lebihan, sehingga sebagian besar waktunya dipakai untuk melakukan tindakan keperawatan secara langsung kepada pasien.

Dokumentasi keperawatan merupakan suatu yang mutlak harus ada untuk perkembangan keperawatan khususnya proses profesionalisasi keperawatan serta mempertahankan keperawatan sebagai suatu profesi yang luhur dan terpandang di masyarakat, karena dengan dokumentasi dapat tercermin mutu suatu asuhan keperawatan yang diberikan. Hal ini menyebabkan masalah penting bagi praktisi keperawatan dalam pendokumentasian asuhan keperawatan kepada pasien. Handayaningsih (2007) menyebutkan bahwa standart dokumentasi menjadi hal yang penting dalam setiap tindakan keperawatan, namun hal ini kadang tidak disadari oleh perawat.

Beberapa hal yang sering menjadi alasan antara lain banyak kegiatan-kegiatan di luar tanggung jawab perawat menjadi beban dan harus dikerjakan oleh tim keperawatan, sistem pencatatan yang diajarkan terlalu sulit dan banyak menyita waktu, tidak semua tenaga perawat yang ada di institusi pelayanan memiliki pengetahuan dan kemampuan yang sama untuk membuat dokumentasi keperawatan sesuai standar yang ditetapkan dan dikembangkan oleh tim pendidikan keperawatan sehingga mereka tidak mau membuatnya. Tenaga keperawatan yang ada berasal dari berbagai jenjang pendidikan keperawatan dan dari rentang waktu lulusan yang sangat berbeda tetapi mempunyai pelayanan klien di ruang rawat inap, serta perawat lebih banyak mengerjakan pekerjaan koordinasi dan limpahan wewenang. Kondisi ketidaklengkapan tersebut banyak ditemukan di Puskesmas, Rumah Sakit ataupun Rumah Bersalin walaupun format dokumentasi sudah disediakan.

Pengetahuan perawat sangat berpengaruh terhadap kelengkapan pengisian dokumentasi asuhan keperawatan. Seorang perawat harus mengisi dokumentasi asuhan keperawatan secara lengkap dan jelas setelah pasien menerima pelayanan. Hal ini sesuai dengan Permenkes No: 269/MENKES/PER/III/2008 pasal 2 ayat 1 yang menyebutkan bahwa rekam medis harus dibuat secara lengkap dan jelas. Rekam medis yang lengkap memuat informasi yang 
berkesinambungan, sehingga dengan adanya kesinambungan informasi tersebut maka setiap pasien yang datang berobat, dokter dan petugas kesehatan lainnya akan memperoleh informasi yang lengkap tentang riwayat penyakit terdahulu secara komprehensif (Shofari, 2002).

Selain itu, dokumentasi asuhan keperawatan mempunyai banyak manfaat dilihat dari berbagai aspek seperti aspek hukum, kualitas pelayanan, komunikasi, keuangan, pendidikan, penelitian dan akreditasi. Rekam medis yang tidak lengkap akan berdampak terhadap kegunaan rekam medis seperti administrasi, legal, keuangan, pendidikan, penelitian dan dokumentasi. Selain itu, ketidaklengkapan rekam medis akan menghasilkan informasi yang tidak tepat dan bersifat legal. Maka dari itu, setiap tenaga kesehatan yang memberikan pelayanan terhadap pasien harus mengisi rekam medis secara lengkap untuk menghindari hal-hal yang tidak diinginkan.

Notoatmodjo (2010) mengemukakan bahwa pengetahuan merupakan faktor yang sangat penting untuk menentukan tindakan seseorang, sehingga perilaku yang didasari pengetahuan akan lebih bertahan lama dibandingkan yang tidak didasari oleh pengetahuan, artinya semakin tinggi pengetahuan seseorang diharapkan semakin baik pula perilaku yang ditunjukannya.

Pengembangan ANNISA ini menghasilkan prototipe terdiri dari model sistem, diagram alur, diagram konteks, dan hierarki input, proses, dan output. Sistem ini memiliki dua dekomposisi, dokumentasi asuhan keperawatan dan fungsi manajemen keperawatan. Sistem ini menghubungkan NANDA-I, NIC, dan NOC untuk membantu perawat dalam melakukan proses keperawatan. Perawat menemukan hubungan ini bermanfaat untuk memiliki dokumentasi keperawatan yang lengkap, berkelanjutan, dan berkualitas. Terminologi keperawatan standar (SNT) memainkan peran penting dalam menggambarkan dan mendefinisikan asuhan keperawatan. SNT dapat memberikan informasi penting untuk pengembangan perencanaan asuhan keperawatan elektronik dalam catatan kesehatan elektronik sebagai bagian dari asuhan keperawatan (Olatubi et al., 2019).

Penelitian ini sejalan dengan penelitian yang dilakukan oleh (Karp et al., 2019) dimana penggunaan aplikasi elektronik health record (HER) dapat meningkatkan pengetahuan perawat tentang dokumentasi keperawatan $(p$ Value $=0,001)$. Hal ini memberikan gambaran bahwa penggunaan model aplikasi pada bentuk EHR dalam praktik dokumentasi keperawatan akan meningkatkan pengetahuan tentang dokumentasi keperawatan baik di rumah sakit maupun di tingkat pelayanan primer. Peningkatan pengetahuan tentang dokumentasi keperawatan setelah 
dilakukan ANNISA juga dapat disebabkan karena adanya modul dan pedoman yang telah disusun sebagai referensi bagi perawat dalam melakukan dokumentasi keperawatan. Dalam pedoman yang telah disusun tersebut sudah memenuhi aspek pengetahuan perawat, terminologi NNN Linkage yang digunakan untuk mendukung peningkatan pengetahuan perawat dalam pendokumentasian asuhan keperawatan yang akan dilakukan.

Peneliti berasumsi bahwa kefektifan penggunaan Aplikasi ANNISA harus didukung dengan karakteristik perawat yang memadai pula. Aspek peningkatan pengalaman perawat, pengetahuan perawat tentang dokumentasi dan nomenklatur NNN Linkage, pengaturan beban kerja perawat lebih efisien akan berdampak langsung terhadap penggunaan aplikasi ANNISA. Tentunya dampak tersebut akan terus dapat ditingkatkan melalui proses peningkatan kemampuan penggunaan aplikasi ANNISA melalui pelatihan dan pembelajaran terus menerus oleh perawat sehingga tujuan akhir dari dokumentasi keperawatan yaitu peningkatan pengetahuan tentang dokumentasi keperawatan dapat terlaksana di Puskesmas Kota Pekanbaru.

Penerapan NANDA-I, NIC, dan NOC dalam pendokumentasian proses keperawatan merupakan salah satu bentuk penggunaan standar bahasa keperawatan (standard nursing language) dalam proses keperawatan. Hasil penelitian ini menunjukkan bahwa ada perbedaan tingkat pengetaahuan perawat tentang dokumentasi sebelum dan sesudah penerapan standar bahasa keperawatan yang berbentuk NANDA-I, NIC, dan NOC

\section{PENUTUP}

\section{KESIMPULAN}

Dokumentasi keperawatan yang berlaku di rumah sakit saat ini umumnya dilakukan secara tertulis (paper based documentation). Metode ini mempunyai kelemahan yaitu memerlukan waktu yang cukup lama untuk mengisi form yang tersedia, membutuhkam biaya percetakan form yang cukup mahal, sering hilang atau terselip, memerlukan tempat penyimpanan yang luas dan menyulitkan pencarian kembali saat diperlukan. Diperlukan inovasi dokumentasi keperawatan dengan menggunakan dokumentasi berbasis elektronik. Dokumentasi keperawatan berbasis elektronik ini memberikan keuntungan bagi perawat dalam hal waktu 
pendokumentasian yang lebih singkat, keterbacaan data dan kemudahan akses bila dibandingkan dokumentasi dalam format kertas.

\section{SARAN}

Diharapkan bagi RS dapat menetapkan kebijakan terkait pelayanan kepe-rawatan yang bermutu dengan meningkatkan kelengkapan dokumentasi keperawatan melalui bidang keperawatan dengan melengkapi format dokumentasi keperawatan dan aturan yang sama untuk setiap ruangan dan memberikan kesem-patan pada perawat untuk mengikutsertakan atau mengadakan pelatihan terkait dokumentasi keperawatan dengan sistem komputerisasi. Bagi penelitian selanjutnya diharapkan dapat mengidentifikasi faktor lain yang berhubungan dengan kelengkapan dokumentasi keperawatan seperti supervisi, motivasi, pemberian reward dan punishment, jumlah ketenagaan perawat, beban kerja dan sebagainya (AS, RR).

\section{DAFTAR PUSTAKA}

Atmanto, Arif, Puji., Aggorowati., Rofii, Muhammad. 2020. EFEKTIFITAS PEDOMAN PENDOKUMENTASIAN DIAGNOSA DAN INTERVENSI KEPERAWATAN BERBASIS ANDROID TERHADAP PENINGKATAN MUTU DOKUMENTASI KEPERAWATAN DI RUANG RAWAT INAP. Jurnal Keperawatan dan Kesehatan Masyarakat, 4(1).

Kusnadi, Elon. 2017. Analisis Kelengkapan Dokumentasi Keperawatan di Ruang Rawat Inap Non Intensive Rumah Sakit X. Jurnal Bidang Ilmu Kesehatan, 9(1).

Mangole, Josua, Edison., Rompas, Sefty., Ismanto, A, Yudi. 2015. HUBUNGAN PERILAKU PERAWAT DENGAN PENDOKUMENTASIAN ASUHAN KEPERAWATAN DI CARDIOVASKULAR AND BRAIN CENTER RSUP PROF. DR. R. D. KANDOU MANADO. E-journal Keperawatan (e-Kp), 3(2).

Noorkasiani, Gustina. R., Siti Maryam. 2015. FAKTOR-FAKTOR YANG BERHUBUNGAN DENGAN KELENGKAPAN DOKUMENTASI KEPERAWATAN. Jurnal Keperawatan Indonesia, 18(1).

Nugraha, Agung, Tri, Hendra. 2012. Hubungan Persepsi Perawat Tentang Manfaat Dokumentasi Asuhan Keperawatan Dengan Kelengkapan Dokumentasi Asuhan Keperawatan Di Ruang Rawat Inap RS PKU Muhammadiyah Yogyakarta. Naskah Publikasi

Nuryani, Nurul., Susanti, Dwi, Dahlia. 2014. HUBUNGAN PENGETAHUAN PERAWAT DENGAN KELENGKAPAN DOKUMENTASI ASUHAN KEPERAWATAN DI RSUD dr.SOEKARDJO KOTA TASIKMALAYA. Jurnal Manajemen Informasi Kesehatan Indonesia, 3(1). 
Olfah, Yustiana., Ghofur, Abdul. 2016. Dokumentasi Keperawatan. Pusdik SDM Kesehatan Badan Pengembangan dan Pemberdayaan Sumber Daya Manusia Kesehatan.

Saputra, Candra., Arif, Yulastri., Yeni, Fitra. 2020. ANDRA'S NURSING INFORMATIC SYSTEM APPLICATION (ANNISA) DALAM UPAYA MENINGKATKAN PENGETAHUAN PERAWAT TENTANG DOKUMENTASI KEPERAWATAN. Jurnal Keperawatan Silampari, 4(1).

S Simamora, R. (2009). Dokumentasi Proses Keperawatan.

Simamora, R. H., Purba, J. M., Bukit, E. K., \&Nurbaiti, N. (2019). PenguatanPeranPerawatDalamPelaksanaanAsuhanKeperawatanMelaluiPelatihanLayanan Prima. JPPM (JurnalPengabdian Dan PemberdayaanMasyarakat), 3(1), 25-31.

Sugiyati, Sri. 2015. HUBUNGAN PENGETAHUAN PERAWAT DALAM DOKUMENTASI KEPERAWATAN DENGAN PELAKSANAANNYA DI RAWAT INAP RSI KENDAL. Jurnal Keperawatan, $8(2)$.

Wulandari, Dyah, Fitri., Handiyani, Hanny. 2019. PENGEMBANGAN DOKUMENTASI KEPERAWATAN BERBASIS ELEKTRONIK DI RS X KOTA DEPOK DENGAN MENGGUNAKAN TEORI PERUBAHAN LEWINS. Jurnal Keperawatan Global, 4(1). 